\title{
A STRATÉGIAI MENEDZSMENT FEJLŐDÉSI IRÁNYAI AZ EZREDFORDULÓT KÖVETŐEN
}

\section{DIRECTIONS OF DEVELOPMENT OF STRATEGIC MANAGEMENT AFTER THE MILLENNIUM}

Az elmúlt 15-20 évben a stratégiai menedzsment jelentős változásokon ment keresztül világszerte. Az új megközelítések a gazdasági, társadalmi, politikai és technológiai változásokra adott válaszokként értékelhetőek. A felgyorsult környezeti átalakulások időszakában elavultakká váltak a korábbi, szisztematikus tervezésre épülő megközelítések. Érthető ezért, hogy a gazdasági válság után új utakat kerestek a vállalatok, mind a viszonylag sikeresek, mind pedig a komoly túlélési problémákkal küzdő társaik. Radikálisan új nézetek jelentek meg, amelyeket indokolt kritikusan szemlélni. Az azonban bizonyosnak tekinthető, hogy a jövőben nem lehetnek sikeresek a vállalatok a korábban alkalmazott stratégiai megközelítésekkel.

Kulcsszavak: stratégiai menedzsment, hálózatelmélet, stratégia mint gyakorlat

During the last 15-20 years strategic management has experienced relevant changes worldwide. The new developments may be evalueted as responses to the economic, social, political and techological changes. In the period of accelerated environmental transformations the foremerly used approaches based on systematic planning have proved to be outdated. It is understandable that after the last economic crises enterprises have been searching for new pathways - both the successful ones and those having serious problems of survival. Radically new concepts have emerged which have to be view though a critical lens. It seems to be sure however that enterprised can not be successful by relying on the previously used strategic approaches.

Keywords: strategic management, network theory, strategy-as-practice

\section{Finanszírozás/Funding:}

A szerző a tanulmány elkészítésével összefüggésben nem részesült pályázati vagy intézményi támogatásban. The author did not receive any grant or institutional support in relation with the preparation of the study.

\section{Szerző/Author:}

Dr. Balaton Károly DSc, egyetemi tanár, Miskolci Egyetem, (szvbk@uni-miskolc.hu) 
A stratégiai menedzsment változásai több tényezőre vezethetők vissza. Egyrészt megváltozott a vállalatok környezete, ami alkalmazkodást igényelt a szervezetek részéről. Ez főleg a stratégiaalkotási folyamatok gyorsabbá és rugalmasabbá tételét követelte meg. Változott a stratégia elmélete is: az erőforrás- és képességalapú stratégiafelfogás a belső tényezőkre irányította a figyelmet, s a stratégiák kidolgozásánál nem csupán a környezeti hatásokra, hanem a belső erőforrásokkal és képességekkel való összhang megteremtésére is törekednek a szervezetek. Megjelent a hálózatelmélet, illetve annak alkalmazása a vállalati struktúrákban, a vállalatközi együttmüködések változatos formáit eredményezve. A külső tényezők közül a változások ütemének felgyorsulását, a globalizáció magasabb szintjének megjelenését emelhetjük ki. E változási folyamatban új követelmények jelentek meg a vállalatok vezetőivel szemben. Felértékelődött a vállalkozó szemléletü, kockázatot vállaló vezetés. A 2000. év után tapasztalt változások egy részének előzményei már az 1980-as és 90-es években megjelentek, de azok gyakorlati alkalmazása a 2000. év után következett be.

\section{A tanulmányban alkalmazott módszerek}

A cikk gondolatmenete kettős szálon fut. Egyrészt igyekszik bemutatni a stratégiai menedzsment gyakorlatának fejlődését, másrész tárgyalja az elmélet fejlődésének fontosabb területeit. A gyakorlati vizsgálat döntően a Versenyben a világgal kutatási program keretében végzett empirikus elemzésekre támaszkodik. Az elmélet a témakör hazai és nemzetközi publikációi közül azokat használja fel, amelyek meghatározóak a stratégiai menedzsment fejlődése szempontjából. Látni fogjuk, hogy a fejlődésnek vannak olyan szakaszai, amikor az elmélet járt élen (mint például az erőforrás- és képességalapú stratégiafelfogás esetében), míg más esetekben a gyakorlat haladt elöre, $\mathrm{s}$ erre reflektált a stratégiai menedzsment fejlődése. Ilyen eset volt például a stratégiaalkotás módszerének megváltozása, azaz a részletes stratégiai tervek kidolgozása helyett a stratégiai koncepciókra való támaszkodás, ami a stratégiaalkotás rugalmasabbá, a környezeti változásokat gyorsabban követő folyamattá vált.

\section{A globalizáció hatása}

A vállalati szintü stratégiai vezetés átalakulását kiváltó tényezőket keresve mindenekelőtt ki kell emelnünk a globalizáció megjelenését és gyors ütemű elterjedését. Az információk, a tőke és a munkaerő nemzetközi áramlásának felgyorsulása oda vezetett, hogy a csupán hazai piacra koncentráló vállalkozásoknak is szembe kellett nézniük a nemzetközi piacokon kialakult versennyel, hiszen a külföldi vállalkozások megjelentek a hazai piacokon is, nem egy esetben komoly konkurenciát eredményezve a lokális vállalatoknak (Balaton, 2015). A gyors ütemü változások alkalmazkodásra kényszerítik a vállalatokat, hogy meg tudjanak felelni a vevői elvárásoknak. Az alkalmazkodás a sikeres vállalatoknál többnyire nem a régi termékek és technológiák alkalmazásával valósul meg, hanem az innováció révén új termék- és szolgáltatáskínálattal.
Magyarország európai uniós csatlakozása 2004-ben felgyorsította a globalizációs hatások hazai megjelenését. Új, korábban nem várt versenytársakként jelentek meg a velünk párhuzamosan csatlakozó közép-kelet-európai országok vállalatai, amelyek egyes iparágakban, pl. a tejiparban jelentős piaci részesedést szereztek a magyar vállalatok kárára (Balaton, 2015). Új, korábban nálunk nem létező iparágak jöttek léte (pl. autóipar) amelyek létrehoztak egy beszállítói hálózatot, amelyben a technológiák új elemei jelentek meg, s korszerű gyártási rendszerek valósultak meg (Gelei \& Mandják, 2011). Hasonlóan gyors fejlődés valósult meg a gyógyszeriparban, az informatikában és a biotechnológiában.

A versenyképesség növelése a magyar gazdaság fejlödési lehetôségeinek alapvető befolyásoló tényezőjévé vált (Chikán \& Czakó, 2009). A hazai gazdaság ugyanakkor jelentősen hátrébb sorolódott a nemzetközi versenyképességi rangsorban. Elemzések szerint hazánk a régión belüli korábbi vezető helyről 2013-ban sereghajtóvá csúszott le a nemzetek versenyképességi listáján a Világgazdasági Fórum jelentése szerint (Chikán \& Czakó, 2014). Különösen aggályos, hogy a hazai tulajdonban lévő kis- és középvállalatoknál a 2013-ban végzett empirikus vizsgálatunkban alig találtunk példákat kutatás-fejlesztési tevékenységre és innovációra (Chikán, 2014).

A világgazdasági átrendeződés folyamatában új hatalmi központok alakultak ki. Kína, India, Brazília, Oroszország (BRIC-államok) - illetve gyakran e csoporthoz sorolják még Dél-Afrikát is - a világ jövőbeli meghatározó gazdaságaiként jelentek meg a gazdasági előrejelzésekben. Kína a világ második legnagyobb gazdaságává nőtte ki magát, India világméretekben meghatározó szerepet tölt be egyes iparágakban (pl. informatika), s növekedési üteme is messze meghaladja a világ átlagát. Brazília és Oroszország jelenleg komoly gazdasági gondokkal küzd, de hosszabb távon jelentős növekedési potenciállal rendelkeznek. Az USA kormánya vámok kivetésével, illetve a korábban külföldön végzett termelö tevékenységeknek az anyaországba való visszatelepítésével kíván javítani a foglalkoztatási helyzeten, valamint az állam pénzügyi egyensúlyán (Gulati, Nohria, \& Wohlgezogen, 2010). Ezek a lépések azonban nem csak pozitív hatásokkal járnak. A termelés USA-beli folytatása a költségek - mindenekelött a munkaerö-költségek - jelentős növekedésével járnak, ami rontja az USA termékeinek világpiaci versenyképességét. Ma még nem megítélhető, hogy az importból befolyó többletadók hogyan viszonyulnak az exportból származó bevételekhez és adókhoz.

A fentebb vázolt világgazdasági átrendeződés időszakában a vállalatoknak fel kell készülniük az új környezeti hatásokra, ami ugyancsak a változás és az innováció szükségességét helyezi előtérbe (Fejes, 2015).

\section{A kutatás-fejlesztés-innováció és az EU- pályázatok kapcsolata}

A nemzetközi versenyben markánsan érzékelhető az Európai Unió lemaradása. Az Unió 2000-ben elfogadott lisszaboni stratégiája azt a célt tűzte ki, hogy az Unió 2010-re a világ egyik leggyorsabban növekedő, s legver- 
senyképesebb régiójává válik. Ezt a cél összekapcsolták azzal, hogy az Unió átlagában 2010-re 3\%-os GDP-arányos $\mathrm{K}+\mathrm{F}$ ráfordítást kell elérni. Ezeket a célokat nemcsak az EU átlagában nem sikerült elérni, hanem egyetlen ország (Finnország) kivételével az összes többi országban sem. Az EU 2005-ben módosította a célokat, s 2020-ig 2\%-os GDP-arányos $\mathrm{K}+\mathrm{F}$ ráfordítást tüzött ki célul (http:// www.bruxinfo.hu/2005.02.03).

A kutatás-fejlesztési ráfordítások azonban nem automatikusan eredményezik az innovációt és azáltal a versenyképesség javulását. Számos hazai vállalatnál tapasztaltuk a 2013-ban készített interjúk során, hogy a kis- és közepes vállalkozások jelentős hányada nem rendelkezik $\mathrm{K}+\mathrm{F}+\mathrm{I}$ stratégiával, s fejlesztéseik olyan témákra irányulnak, amelyekhez EU-forrásokat lehet szerezni (Chikán, 2014). Ezen esetekben csupán a költségkeretek felhasználása tekinthető biztosnak, ugyanakkor nagyon bizonytalan, hogy lesz-e piacképes innováció a pályázathoz kapcsolódóan. Szükséges lenne tehát, hogy a kis- és középvállalatok is alakítsanak ki innovációs stratégiát, $\mathrm{s}$ annak megvalósításához igényeljenek EU pályázati forrásokat. Az innovációs stratégia létezése önmagában nem garantálja a sikert. Szükség van a végrehajtást támogató vállalati rendszer kialakítására is, azaz a stratégia, a vállalati folyamatok és struktúrák, a kultúra és a szervezeti magatartás megváltoztatására is.

Megítélésünk szerint a magyar gazdaság versenyképességének javításához nélkülözhetetlen az innováció, s annak beépülése a vállalatok müködésébe. A folyamatos megújulás, amely érinti az üzleti modelleket is, nyújthatja azokat a vállalati képességeket, amelyek az üzleti sikert biztosíthatják a gyorsan változó feltételek esetén (Fejes, 2015).

\section{A nagyfokú külső bizonytalanság vállalati kezelése, a stratégiai tervezés kudarca}

A nagyfokú bizonytalanság kezelésére fejlesztették ki és alkalmazzák az innovatív vállalatok az ún. „,korai figyelmeztetö rendszereket” (early warning systems) (Goldstein, Kaminsky \& Reinhart, 2000). E rendszerek az információforrások széles körét vizsgálják (pl.: sajtóhírek, szállítók véleménye, vevők véleménye, versenytársak megítélése, gazdaságkutató és közvélemény-kutató intézetek tanulmányai, egyetemi kutatók véleménye). Az így begyüjtött véleményeket kritikai elemzésnek vetik alá, hiszen lehetséges például, hogy egy versenytárs irigységből, vagy presztízsrombolási szándékkal adott negatív véleményt a vállalatról. A relevánsnak bizonyuló információk alapján hozzá kell kezdeni a vállalati müködés átgondolásához és a változtatásokat elindító döntések meghozatalához.

A világgazdasági válság, s annak gyors ütemű terjedése új kihívások elé állította a világ gazdagabb államait is. A 2008 szeptemberében kirobbant válság a korábbiakhoz viszonyítva nagyságrendekkel gyorsabb ütemben terjedt szét a fejlett gazdaságokban (Gulati, Nohria, \& Wohlgezogen, 2010). Hazánkban kezdetben az volt a hivatalos álláspont, hogy a válság nem fog jelentős hatást gyakorolni a magyar gazdaságra. Két hónappal később az MNB arra koncent- rálta erőit, hogy el tudjuk kerülni a magyar gazdaság fizetésképtelenségét. A válság a hálózatokra jellemző horizontális kapcsolatrendszereken keresztül terjedt el a világban, amelynek mechanizmusairól ma is kevés információval rendelkezünk (Barabási, 2016). A bürokratikus berendezkedés, az igazi vezető egyéniségek hiánya a változó körülményekhez való lassú alkalmazkodásban nyilvánul meg. A fentiekben vázolt tényezők a gazdasági vállalkozások környezetét rendkívül kiszámíthatatlanná tették. Emiatt a stratégiai vezetésben korábban alkalmazott - alapvetően a tervezésre támaszkodó - módszerek elavultakká váltak (Mintzberg, 1994). Újak keresésére volt szükség ahhoz, hogy a vállalatok meg tudják örizni versenyképességüket. Az 1970-es és 80-as években uralkodó stratégiai megközelítés a környezeti alkalmazkodást állította a középpontba. Ez arra a logikus gondolatra épült, hogy a vállalati stratégiáknak alkalmazkodniuk kell a mindenkor fennálló környezeti feltételekhez (Porter, 1980), tehát az adaptáció a stratégia kialakításának központi kérdése kell, hogy legyen.

A vállalatok stratégiai tervezésében azonban egyre nagyobb gondot jelentett a gyorsuló ütemű környezeti változások megjelenése. Különösképpen érzékelhető volt a hetvenes években kialakult részletes, bürokratikus stratégiai tervezési rendszerek jelen körülmények közötti alkalmazása során. Nagyobb méretü vállalatoknál a stratégiai tervek kidolgozása gyakran egy, másfél éves folyamatot jelentett. Emiatt rendszeresen előfordult, hogy mire készen lett a stratégiai terv, az máris elavult volt (Mintzberg, 1987).

A nyolcvanas évek elején megjelent változtatás eredményeként a vállalatok a részletesen kidolgozott stratégiai tervekkel szemben a rövidebb, de gyorsabban kidolgozható és megváltoztatható stratégiai koncepciókat kezdték preferálni, hogy könnyebben összhangba tudják hozni a stratégiai irányvonalat és a környezeti feltételeket (Balaton et al., 2010). A stratégiai irányvonalat összehangolták a szervezet egyéb jellemzőivel: struktúra, kultúra, személyzet, vezetési stílus, irányítási és ellenőrzési rendszerek. Az így kialakított ún. 7S modell a szervezet teljes részvételét hangsúlyozza a környezeti alkalmazkodás során (Balaton et al., 2010). Bármelyik elem megváltozik a hétből, meg kell vizsgálni, hogy milyen változtatások szükségesek a többi összetevőben ahhoz, hogy az összhang megmaradjon a szervezeten belül.

\section{A szcenáriótervezés}

Az 1970-es és 80-as években uralkodó stratégiai megközelítés a környezeti alkalmazkodást állította a középpontba. Ez arra a logikus gondolatra épült, hogy a vállalati stratégiáknak alkalmazkodniuk kell a mindenkor fennálló környezeti feltételekhez, tehát az adaptáció a stratégia kialakításának központi kérdése kell, hogy legyen (Porter, 1980).

A környezeti változások üteme és intenzitása a 80-as években tapasztalthoz viszonyítva lényegesen felgyorsult az ezredforduló utáni években. Ekkor már különös gondot okozott a vállalatok (elsősorban a nagyméretű és bürokratikus struktúra kereteiben müködők) számára a gyors alkalmazkodás.

A szcenáriótervezés alapgondolata az, hogy a környezet folyamatosan változik, de nem tudjuk pontosan meg- 
mondani, hogy milyen irányú lesz a változás. A szenáriótervezés ezért nem egy konkrét jövőbeli állapotot próbál meghatározni, hanem a változások által érintett sávot (Bowman, 2015). Geometriai példával illusztrálva a szenáriótervezés egy körszeletet próbál kijelölni a változások lehetséges irányát és terjedelmét illetően.

Erre a sávra próbálja meg definiálni a változásokat irányító tényezőket, (tényezőváltozók), valamint a változások által érintet változókat (eredményváltozók). A változásokat előidéző és az eredményváltozók közötti összefüggések feltárása ad lehetőséget a vállalat számára, hogy oly módon alakítsa a változást előidéző tényezőket, hogy azok a vállalat számára kedvező eredményváltozókat idézzenek elő (Schoemaker, 1995).

\section{Az erőforrás- és képességalapú stratégiafelfogás elterjedése}

A 80-as években jelent meg, majd a 90-es években fejlödött ki a stratégia erőforrásokra és képességekre alapozó felfogása. Az új koncepció szerint a vállalati stratégiaalkotás középpontjába nem a környezethez való alkalmazkodást kell állítani, hanem a vállalat meglévő erőforrásaira és képességeire kell építeni a stratégiát ahhoz, hogy a vállalkozás tartósan sikeres lehessen. A stratégia kialakítása az alábbi logikára épült (Grant, 1991):

- először is azonosítani kell a vállalat meglévő erőforrásait, ennek során a fizikai, pénzügyi, személyi és szellemi erőforrásokat egyaránt figyelembe kell venni,

- ezután fel kell mérni, hogy a meglévő erőforrások felhasználásával a vállalat milyen képességekre tud szert tenni,

- a következő lépés annak azonosítása, hogy a meglévő erőforrások és képességek alapján a vállalat milyen jövedelemtermelési képességekkel rendelkezik,

- ezután ki kell választani azokat a stratégiákat, amelyek leginkább ki tudják használni a vállalati képességeket,

- a következö lépésben rögzíteni kell a követendő stratégiákat,

- a folyamat utolsó lépése a meglévő képességbeli hiányosságok azonosítása, majd azok megszüntetése.

A vállalati stratégiák fenti logika alapján történő kialakítása a kilencvenes évek közepe óta vált szélesebb körben alkalmazottá. A gyakorlatban azonban kiderült, hogy az egy időpontban meglévő erőforrások és képességek a gyors környezeti változások időszakában hamar elavultakká válhatnak, illetve a versenytársak előbb vagy utóbb megszerzik ezeket az erőforrásokat és képességeket, s megszünik a vállalat versenyelőnye.

Az elméleti irányzaton belül az első fejlődési lépést a komplex képességek előtérbe kerülése jelentette. Ez azt jelentette, hogy nem egyedi erőforrásokra és képességekre kell a hangsúlyt helyezni, hanem azok összetett kombinációira. Ezen erőforrás- és képességkombinációk nemcsak a kodifikált (rögzített), dokumentumokban hozzáférhető képességekre építenek, hanem azok nehezen kiismerhető és másolható kombinációira. Minél összetettebb egy képesség, annál nehezebb annak másolása, illetve más vállalatokhoz való átvitele.
A fejlődés következő lépcsőjében megjelent a dinamikus képességek koncepciója, illetve annak gyakorlati alkalmazása. A felfogás abból indul ki, hogy bármennyire is összetettek a vállalat által birtokolt erőforrások és képességek, azok csak korlátozott ideig képesek versenyelőnyt nyújtani a vállalat számára (Ambrosini \& Bowman, 2009). Ennek magyarázata egyrészt abban van, hogy a versenytársak egy idő után el tudják sajátítani azokat, másrészt pedig a környezeti változások következtében a meglévő erőforrások és képességek elavultakká válhatnak, s ezért szünik meg a vállalat versenyelőnye.

A feladat tehát az, hogy folyamatosan fejleszteni és tökéletesíteni kell a képességeket, hogy mindig a versenytársak előtt tudjon járni a vállalat. Ezt fejezi ki a dinamikus képességek koncepciója, tehát a vállalat vezetésének a folyamatos megújulásra kell törekedni, s ily módon biztosítani a versenyelőnyt. Az aktív környezeti alkalmazkodást segítheti a vállalatok által alkalmazott üzleti modellek, illetve azon megújítása. Egyes felfogások szerint a dinamikus képességek jelenléte egy vállalatban az üzleti modellek megújítási képességét jelzi (Bohl, 2015). E gondolatmenetet követve a vállalat ,átmeneti versenyelőnyre" (transient advantage) tehet szert, s folyamatosan dolgozva azon elérheti, hogy az egymást követö átmeneti versenyelönyök hosszabb távon is elönyös pozíciót biztosíthatnak a vállalat számára (McGrath, 2013).

A képességek fejlesztésében fontos szerepe van a szervezeti tanulásnak. A tanulás irányulhat egyrészt a múltbeli tapasztalatok feldolgozására (learning by exploitation), másrészt a kísérletezés révén történő új tudás megszerzésére (learning by exploration) (March, 1991). A gyakorlati tapasztalatok azt mutatják, hogy nehéz a kétféle tanulás egyidejű alkalmazása egy vállalatnál. A múltbeli tapasztalatokra épülő tanulás gyakran elnyomja a kísérletezést, s elmarad a vállalat megújulása (Fejes, 2015). Fordítva is elöfordulhat az egyoldalú tanulás, amikor a kísérletezés preferálása miatt nem fordítanak kellö figyelmet a javításra, tökéletesítésre, azaz a tapasztalatok alapján történő tanulásra.

A vezetéstudomány egyik fö kérdése, hogy miképpen lehet egyidejüleg megvalósítani a múltbeli tapasztalatok feldolgozását és a kísérletezés útján történő tanulást (Popadiuk \& Souza Bido, 2016). Az eddig alkalmazott megoldások fajtái:

- a felső vezetők között megosztják a kiaknázással és a kísérletezéssel kapcsolatos feladatokat,

- a középvezetői szinten alakítanak ki az egyik, illetve a másik tanulási típussal foglalkozó vezetői pozíciót,

- az elsőszámú vezető feladatává teszik a kétféle tanulás összehangolását,

- külső partnereket vonnak be egyrészt a kiaknázási feladatokra, másrészt a kísérletezéssel való tanulás megoldására (Smith \& Tushman, 2005).

Mindegyik fenti megoldásnak vannak előnyei és hátrányai, s a konkrét szervezeti kontextus, illetve az érintett személyek képessége határozza meg, hogy mennyiben lehet eredményes az egyik vagy másik megoldás. Az eredményes megoldás az ún. „kettős képességű szervezetet” (azaz olyan szervezet, amely egyidejűleg képes a rövid 
távú hatékonyság és a hosszabb távú fejlődés megvalósítására), amely a mai üzleti viszonyok között sikerrel alkalmazható.

A szervezeti képességek fejlesztése révén elérhető tartós versenyelőny koncepciójának kritikája is megjelent a szakirodalomban. McGrath (2013) cikke kétségbe vonja a tartós versenyelőny elérésének lehetőségét a jelenlegi, gyorsan változó környezeti feltételek közepette. A szerzö szerint a reális lehetőség az átmeneti versenyelőny elérése, amely egy adott környezeti feltételrendszer érvényesülése esetén lehetséges. A feltételek megváltozása esetén újra kell gondolni a vállalati stratégiát és a müködési folyamatokat, hogy a vállalat az új körülmények között is meg tudja szerezni a versenyelőnyt. A felkészülést akkor kell elkezdeni, amikor még rendelkezik versenyelőnnyel a vállalat, ezáltal érheti el, hogy megfelelö választ tud adni az újonnan megjelenő környezeti állapotokra.

\section{A stratégia mint gyakorlat}

A 2000-es évek elején jelent meg a stratégia mint gyakorlat (strategy as pactice) koncepció (Jarzabkowski, 2004). Az új felfogás elterjedése válaszként jelent meg a korábban megjelent kritikákra, amelyek kifogásolták, hogy a stratégia elmélete és gyakorlata elszakadt egymástól (Mintzberg \& Quinn, 1991). A koncepció a stratégia gyakorlati megjelenését három fogalom alapján vizsgálja: stratégiai folyamatok, a stratégiaalkotás szereplői és az alkalmazott módszerek (Whittington et al., 2017). Vizsgálódásai a tényleges végbemenő folyamatokra helyezik a hangsúlyt a szervezeti stratégiák kialakulása során.

A megközelítés a stratégia kialakítását és végrehajtását mint egymást követő és visszacsatolásokkal megvalósuló folyamatot tekinti. Ez egyúttal megváltoztatja a stratégiai menedzsmenttel foglalkozó szakemberek feladatait (Whittington et al., 2017). A részletesebb elemzések kiterjednek a stratégiai tervezéssel foglalkozók szerepére, az alkalmazott normákra és rutinokra, a stratégiai tervezési eljárásokra és a tervezők konkrét tevékenységeire (Balaton \& Regele, 1996; Balaton \& Kerek, 2012).

\section{A hálózatelmélet alkalmazása}

A szervezetek a hagyományos felfogás szerint hierarchikus rendszerek, amelyekben az irányítás a szervezet felső szintjeiről indul ki, s utasításokkal, illetve szabályokkal, vagy ösztönzési eszközök alkalmazásával irányítja az alsóbb szinteken lévő szervezeti egységeket vagy személyeket. Az alá- és fölérendeltségi viszonyok tehát alapvető jelentőségűek a szervezetek életében. Ezt a felfogást alakította ki a klasszikus iskola, de ezzel számolt az emberi viszonyok iskolája és a döntéselmélet is (Dobák et al., 2006).

Az azonos szinten lévő egységek (személyek) közötti kapcsolatot a felettes szervezeti egység (személy) biztosította. Hazánkban is hosszú időszakon át érvényesült ez a szervezeti felfogás. A II. világháború után kialakult szocialista tervgazdasági rendszer is erre a szervezeti modellre épült, azzal a sajátossággal, hogy a legtöbb szervezeti döntés a hierarchia felsőbb (politikai) szintjein született a gazdasági ügyekben is. A rendszer merevsége, a körü- löttünk lévő világ változásai egyre gyakrabban jelezték, hogy elavult ez a modell, de - a politika primátusa alapján - annak megváltoztatására nem volt lehetőség. Részben ezzel is magyarázható, hogy a hazai vállalatok nem tudtak intenzív üzleti kapcsolatokat kialakítani a tőkés gazdaságok vállalataival. A szükséges horizontális kapcsolatokat ugyanis megzavarta a felsőbb szintek hierarchikus beavatkozása. A vezetők ebben a helyzetben „Janus arcú” vezetők képét mutatták (Dobák et al., 2006), akiknek egyik arca felfelé - a hierarchia felsőbb szintjei felé mutat, másik arca pedig oldalirányba - az üzleti partnerek felé. A kettő együtt nem lehetséges, s előidézi a kognitív disszonancia jelenségét az érintett vezetőknél (Kindler, 1974).

A gyakorlatban ez a disszonancia úgy oldódott fel, hogy a vállalati vezetők a felsőbb hierarchia követelményeihez igazodtak, hiszen attól függött mind a vállalat jövőbeli lehetősége (akár a fennmaradása is), valamint a vezetők pozícióinak megőrzése és a javadalmazásuk. A fentebb említett „Janus arc” úgy vált „egyarcúvá”, hogy a vezetők kiiktatták a horizontális kapcsolatokkal való foglalkozást, s a hierarchia követelményeivel azonosultak (lásd: a politikai megbízhatóság szerepe a vezetőkkel szemben a rendszerváltást megelőzően.) A rendszerváltást követően gyors ütemben (ugyan az állami vállalatoknál viszonylag lassabban) leépült a hierarchikus alárendeltség a vállalatok és a felügyeleti szerveik viszonyában, $\mathrm{s}$ a piaci kapcsolatokra koncentrálhattak a vállalatok.

A hálózatok létjogosultsága a hierarchia leépülésével párhuzamosan egyre fontosabb szerepet kapott. Ebben a tanulmányban nem foglalkozunk a hálózatok valamennyi típusával és azok irányultságával, hanem a vállalaton belüli, illetve a vállalatok (és más szervezetek, intézmények) közötti horizontális kapcsolatokra koncentrálunk. A hálózati kapcsolatok egyes formái már a rendszerváltozást megelőzően megjelentek és müködtek. Gondoljunk itt a vállalatközi termék- és információáramlásra, a személyes kapcsolatokra, a fővállalkozói rendszerekre, a helyi piaci kapcsolatokra, a magángazdaság létező elemeire. A rendszerváltást megelőző évtizedben a nagyvállalatokon belüli gazdasági munkaközösségek (VGMK, azaz vállalati gazdasági munkaközösség), az önálló jogi személyként megjelenő Gazdasági Munkaközösségek, (GMK), a helyi társulások fontos tapasztalatokat nyújtottak a magángazdaság piaci viszonyok közötti kifejlődéséhez.

A vállalaton belüli horizontális kapcsolatokat felhasználó hálózatok fontos szerepet kaptak a termék- és információáramlás működtetésében, s ezáltal a vevői igények korábbinál sokkal rugalmasabb kielégítésében. A kutatás-fejlesztés-beszerzés-termelés-készletezés-értékesítés-értékesítés utáni szolgáltatások tevékenységláncolata az egyik legfontosabb elem a vállalatokon belüli hálózati kapcsolatokban. Feltétlen említést érdemelnek a vállalatok közötti hálózatok, amelyekkel a szervezetközi logisztika, a JIT-termelésirányítás és más üzleti területek foglalkoznak (lásd pl. Chikán, 2008; Szász \& Demeter, 2017).

A vállalaton belüli hálózatosodásnak van egy másik vetülete is, amely témánk szempontjából legalább olyan fontos, mint a termék- és információáramláshoz kapcsolódó hálózatok. A szocialista rendszertől örökölt nagyvál- 
lalatok felbomlásával sajátos vállalatközi hálózatok alakultak ki. A Dunai Vasmű például 20 jogi személyiséggel rendelkező vállalatcsoportra bomlott, de hasonló példákkal találkozhatunk a Videotonnál, a Bakony Müveknél, s még hosszan sorolhatnánk ezeket a példákat (Bühner, Dobák \& Tari, 2002). E vállalatcsoportok sajátossága, hogy az irányításban mind a hierarchikus, mind pedig a hálózatos elemeket felfedezhetjük. Hierarchikus irányítás jellemzi például azokat a vállalatcsoportokat, ahol a termelési folyamat több önálló vállalat részvételével valósul meg. Ilyen esetben célszerű fenntartani a hierarchikus irányítást a termeléstervezés és programozás szintjén, hogy a folyamatos termékáramlás megvalósulhasson. Más területeken viszont a hálózatos irányítás elemei dominálnak.

\section{A hálózatok és klaszterek szerepének felértékelődése}

A vállalatok múködésére hosszú ideig az volt a jellemző, hogy a tevékenységek integrált szervezeti keretek között valósultak meg, s a hierarchikus irányítás koordinálta a tevékenységeket. A környezeti változások felgyorsulása, valamint a számítógépes hálózatok megjelenése oda vezetett, hogy a vállalatok egyre több tevékenységet szerveztek ki vállalaton kívülre, s vállalatközi együttmüködés keretében valósulnak meg az összetett tevékenységek.

Ez a folyamat eredményezte a hálózatok elterjedését, amely a piac és a hierarchia közötti megoldást jelenti (Thorelli, 1986). Jól látható ez a fejlődés például az autóiparban, az építőiparban, de a gazdasági és társadalmi élet más területein is. A hálózatok alkalmazásával a vállalatok sokkal rugalmasabban tudnak alkalmazkodni a változó feltételekhez, s alacsonyabb költségek mellett tudják megvalósítani a tevékenységeket, mint az integrált hierarchikus szervezetek.

A hálózatok sajátos formáját képviselik a klaszterek, amelyek földrajzilag közel lévő, s szoros együttmüködésben megvalósuló szervezeteket jelentenek (Boeva, Lundberg, Kota, \& Sköld, 2018). Ennek leghíresebb példája a Szilícium-völgy, de Európában is számos klaszter alakult ki, pl. Észak-Olaszországban a sonka és csempe klaszterek, a Ruhr-vidéki ruházati klaszter stb. A klaszterbe tartozó vállalatok összehangolják stratégiai törekvéseiket, s szorosan együttmüködnek azokon a funkcionális területeken, ahol kölcsönös előnyök elérésére van lehetőség (pl.: közös beszerzés, közös értékesítés). A vállalati alaptevékenységeket (pl. termelés) általában nem osztják meg egymással a klasztertagok. Példa erre az Észak-Olaszországban müködő St. Danielle sonkaklaszter, ahol az együttmüködés a beszerzés és értékesítés mellett kiterjed a munkaerő-biztosításra is. A helyi önkormányzatok bevonásával közösen alakítják ki a szakképzést, ami a klasztertagok szakemberellátását biztosítja (Chikán, 2008). A termelést (a sonka elöállítását) az egyes tagszervezetek saját belső ügyének tekintik, s nem osztják meg egymás között a tapasztalatokat.

Hazánkban a klaszterek eddig kevés sikeres példát mutattak, amelynek egyik magyarázó tényezője a bizalom hiánya a potenciálisan együttmüködő szervezetek között (Gelei \& Mandják, 2011). A klaszterek létrejötte nem je- lenti a hierarchikus irányítás megszünését. Egy vállalat például lehet egy hierarchikus nagyvállalat egyik divíziója, amely ugyanakkor klaszterhez kapcsolódik a saját müködési körén és földrajzi körzetén belül. Ilyen esetben a nagyvállalat hatásköri rendszerében kell szabályozni a klasztertag divízió önállóságának területeit, illetve korlátait. A klaszterek fő előnye, hogy munkamegosztást alakítanak ki egymás között, s közösen oldanak meg olyan feladatokat, amelyek valamennyi klasztertag számára hasznosak. Észak-Olaszországban például számos borászati klaszter jött létre, amelyek közösen oldják meg az értékesítési feladatokat pl. a nagy áruházi láncok felé. Egyedül a kisebb borászat nem lenne képes arra, hogy olyan mennyiségben szállítson standard borokat, amely mennyiség megfelel az áruházlánc igényeinek (lásd: Chikán, 2008).

A fentiekben tárgyalt szervezeti strukturális megoldások csak akkor vezethetnek eredményre, ha azok megfelelő szemléletű vezetéssel párosulnak. A következő részben ezt a követelményt fejtjük ki.

\section{A vállalkozó vezetés jellemzői}

A bizonytalan és gyorsan változó környezetben müködő vállalkozásoknál a siker részben azon múlik, hogy rendelkeznek-e olyan vállalkozói képességekkel rendelkező vezetőkkel, akik alkalmasak arra, hogy szembenézzenek a kihívásokkal, s azokra újszerű válaszokat adjanak (Hortoványi, 2010).

A vállalkozó vezetők (Raposo et al., 2011) a bizonytalanságot természetesnek tekintik, hiszen az új lehetőségeket kínál a vállalat számukra. Nagyfokú innovációs készség jellemzi őket, keresik az újdonságot, s ennek érdekében kockázatokat és konfliktusokat is felvállalnak. Jellemzőjük a proaktivitás, azaz elébe menni a várható változásoknak, sőt megpróbálják befolyásolni a változások irányát. Magas a bizonytalanságvállalási hajlandóságuk, ebben a környezetben érzik jól magukat. A tanulás iránti igényük meghaladja az újdonságokkal szembeni aggályaikat és félelmeiket. Erős versenyszellem jellemzi őket. Nem az árral való sodródásra törekszenek, hanem a trendek meghatározását tekintik feladatuknak. A változtatások keresztülvitele érdekében nagyfokú az autonómia iránti igényük, szeretik irányítani az eseményeket, s nem kedvelik a szoros irányítást és ellenőrzést (Hortoványi, 2010a).

A szociológiai szakirodalom a vállalkozó vezetőket a „,belülröl irányított” vezetők kategóriájába sorolja (Nemes, 1981). A belülről irányított vezetői szerepfelfogást a kezdeményezőkészség, a kockázatvállalási hajlandóság, a konfliktusok felvállalása jellemző a magasabb szintü eredmény elérése érdekében. Úgy fogják fel vezetői szerepüket, hogy ők mozgatják az eseményeket, s meghatározzák a haladás irányát. Ellentétük a „kívülről irányított” vezető, akire az a jellemző, hogy igyekszik megfelelni az elvárásoknak, kerüli a kockázatokat és a konfliktusokat, jó személyes kapcsolatok kialakítására és ápolására törekszik.

Piacgazdasági körülmények között határozott igény van a belülröl irányított, azaz vállalkozó vezetőkre. Probléma viszont, hogy a működő oktatási rendszerek nem igazán kedveznek a vállalkozó vezetők kinevelésének. 
Szerte a világon a business school-ok oktatási programjaiban a technikák, módszerek elsajátításán van a hangsúly, s a kreatív gondolkodási képességek kifejlesztése hátrányban marad. Harold Levitt három típusú vezetőt különböztetett meg: iránykijelölő (pathfinder), problémamegoldó és megvalósító vezető (Leavitt, 1987). Az iránykijelölő vezető nem merül el a napi problémák megoldásában, azokat beosztottjaira bízza. Ô a jövő lehetőségeivel, a hosszabb távú perspektívákkal foglalkozik. Ezek a koncepciók alapozzák meg a vállalat jövőbeli stratégiáit. Az iránykijelölő vezető tulajdonságai sok tekintetben hasonlóak a vállalkozó vezető jellemzőihez (Leavitt, 1987).

A problémamegoldó vezetők rengeteg adattal dolgoznak, azokat elemezve próbálnak megoldást találni a felmerült döntési helyzetekben. A strukturáltság, a részletes szabályozottságra törekvés jellemzi a vezetői tevékenységüket.

A megvalósító vezető kiemelkedő képességekkel rendelkezik az emberek meggyőzésében és motiválásában. Képes elfogadtatni elképzeléseit, s a beosztottak felsorakoznak mögötte, s támogatják a kiadott feladatok végrehajtását.

Leavitt (1987) véleménye szerint egy vállalatnál mindhárom vezetői típusra szükség van. Tapasztalatai szerint az Egyesült Államok vállalatainál az a probléma, hogy alig lehet találni iránykijelölő vezetőket. E jelenség oka a szerző szerint az egyetemi oktatásban rejlik. Megjegyzi, hogy a business school-okban szinte minden tárgy az elemzéssel foglalkozik: pénzügyi elemzés, piac elemzés, költségelemzés, piaci részesedés elemzése stb. Az egyetem tehát megtanít a technikák elsajátítására és alkalmazására, de nem készít fel az önálló, kreatív gondolkodásra. A szerző szerint oktatási reformra lenne szükség ahhoz, hogy nagyobb számban legyenek a kreatívan gondolkodó, iránykijelölő vezetők (Leavitt, 1987).

A hazai vállalati gyakorlatban a rendszerváltást követően megjelentek a vállalkozó vezetők, többen széles körben is ismertté váltak. Lásd például Bojár Gábort, aki alapítóként és fő tulajdonosként sikerre vezette a Graphisoft vállalatot. A vállalkozó vezetők száma gyarapodik, főleg az újonnan alapított kisvállalatok vezetői körében. Az ilyen tulajdonságokkal rendelkező vezetőkre nagyobb számban lenne szükség, s nem csupán a kisvállalkozásoknál. Az angol szakirodalomban megjelent a ,vállalaton belüli vállalkozás" kategóriája (entrepreneurship in established firms), ami általában úgy jön létre, hogy a vállalaton belül olyan szervezeti egységeket alakítanak ki, amelyek más elvek alapján müködnek, mint a vállalat hagyományos egységei. Nagyfokú önállósággal rendelkeznek, s elsődleges feladatuk, hogy újdonságot (ami lehet termék, szolgáltatás, gyártási eljárás is) hozzanak létre. Amennyiben az új kezdeményezés sikeres, akkor beépül a vállalat hagyományos szervezetébe, s az ,új vállalkozási divízió” újabb innovációk létrehozásán dolgozik (Burgelman, 1985).

A fentiekben leírtak nem jelentik azt, hogy kizárólag vállalkozó típusú vezetőkre van szükség a vállalatoknál. Emellett kellenek ún. adminisztratív típusú (Hortoványi, 2010 b) vezetők is. A kérdés az, hogy milyen arányban vannak az egyes szervezetekben a különböző tulajdonságokkal rendelkező vezetők. A probléma hazánkban (és más országokban is régiónkban) abban van, hogy kevés a vállalkozói tulajdonságokkal rendelkező vezető, ami akadályozza a vállalatok sikerességét. Gyorsan változó, dinamikus környezetben ugyanis a vállalkozó vezető tulajdonságai nélkülözhetetlenek az üzleti sikerhez (Raposo et al., 2011) .

\section{Mennyiben használhatóak a jövőben az eddig alkalmazott stratégiaalkotási megközelítések?}

A fentiekben láthattuk, hogy az üzleti világ gyorsuló ütemü változásai új lehetőségeket és kihívásokat jelentenek a vállalatok vezetői számára. A nemzetközi kutatások azt mutatják, hogy stratégiára a gyorsan változó környezeti feltételek között is szükség van, sőt ilyen körülmények fennállása esetén sokkal inkább szükség van a stratégiára, mint stabil körülmények közepette (Grant, 2003). Az igazi kérdés tehát az, hogy milyen tartalmú stratégiák és milyen stratégiaalkotási folyamatok szükségesek a mai körülmények között az üzleti sikerhez.

Felmerül a kérdés ekkor, hogy mennyiben alkalmazhatóak az eddigi stratégiaalkotási módszerek a megváltozott körülmények között. Ez a gondolatkör már régóta jelen van a stratégiai menedzsment szakirodalmában. Mintzberg már az 1980-as években arról írt, hogy a stratégiai tervezés helyett a stratégiai gondolkodást kell előnyben részesíteni. Azaz nem a részletesen kidolgozott terv a fontos, hanem az, hogy a vállalat rendelkezzen jól átgondolt koncepcióval a jövőbeli működésére vonatkozóan (Mintzberg, 1990).

Evans és Wurster (2000) szerint az internet radikálisan átalakítja az iparágakat, emiatt az iparágelemzés Porter által kidolgozott modellje (Porter, 1980) jelentős változtatásokra szorul. Véleményük szerint az eddig alkalmazott, racionális döntéshozatalra és formalizált eljárásokra épülő módszerek haszontalanok a jövőben, ezek helyett új megoldásokat kell kitalálni. A szerzők szerint a káoszelmélet nyújthatja a megoldást, azaz a fizika bizonytalansággal kapcsolatos törvényeinek megismerése és alkalmazása szükséges.

Eisenhardt és Sull (2001) szintén a korábban alkalmazott elemzési módszereket kritizálják. Véleményük szerint nem a részleteket feltáró elemzések kellenek, hanem néhány egyszerü hüvelykujj-szabály, amely alapján a vállalat kialakíthatja, illetve szükség esetén megváltoztathatja stratégiáját.

A fenti - sokszor radikális - nézetekben jogosnak tekinthető a változás igényének kifejeződése. Mindazonáltal nem hiszem, hogy emiatt minden eddig használt megközelítést és módszert ki kellene dobni. A tapasztalatok inkább azt mutatják, hogy a korábbi, és a változásoknak jobban megfelelő új módszerek együttes alkalmazása a kívánatos a jövőben. A helyzet hasonló ahhoz, amit March professzor a múltbeli tapasztalatokon, illetve a felfedezésen alapuló stratégiaalkotás kapcsán kifejtett (lásd fentebb), azaz, hogy a kettő összhangjának megtalálása jelentheti a hosszabb távon is sikert ígérö megoldásokat (March, 1991).

A stratégiaalkotás módszereinek megváltoztatását a kialakult szabályok, rutinok is befolyásolják, s korlátozhatják a változtatások. A szervezetelmélet szerint a szer- 
vezeti tagok szembenéznek az „útfüggőség” problémájával, azaz hogy a korábban alkalmazott gondolkodásmód és gyakorlat befolyásolja a jelenbeli, illetve a jövőre irányuló gondolkodásunkat. Emiatt gyakran késik az új megközelítések elfogadása. Mintzberg szerint a stratégiai menedzsment legfontosabb feladata, hogy felismerje, meddig célszerủ az eddig alkalmazott módszereknél maradni, illetve mikor kell váltani és új környezet-stratégia-szervezet konfigurációkat kialakítani (Mintzberg et al., 1998).

Az útfüggőségnek van egy személyes és egy szervezeti dimenziója. A szervezeti dimenzió azt jelenti, hogy a szervezeti rutinok, szabályok a múltbeli müködési mód irányába terelik a konkrét jelenlegi feladatok megoldását, a döntések meghozatalát, ezáltal viszont akadályozzák az újszerü megközelítéseket. Az útfüggőség egyéni dimenziója azt jelenti, hogy az emberek többségére jellemző, hogy analógiákat keres a felmerült problémák megoldására, ismert típusokba igyekszik besorolni az újonnan felmerült megoldásokat (Simon, 1982.) Amenynyiben sikerült egy típusba besorolni a problémát, akkor az adott típusnál alkalmazott megoldások közül választhatunk a probléma megoldása érdekében. A kiválasztott megoldási módszerek véletlenszerüek is lehetnek, azaz éppen az a módszer került a döntéshozó elé, minden szisztematikus és tudatos szelekció nélkül. James March és szerzőtársai évtizedekkel korábban a döntéshozatal „szemetes kanna" modelljeként írta le ezt a problémát (Cohen, March \& Olsen, 1972).

\section{Összefoglalás}

A vállalatok vezetésének alkalmazkodnia kell a változó környezeti feltételekhez. Mint azt fentebb láttuk, az elmúlt 15 évben jelentős átalakulások mentek végbe a vállalkozások társadalmi, politikai, technológiai és gazdasági környezetében. A stratégiai menedzsmentben bekövetkezett változások nagyrészt a változó gyakorlati igényekkel és lehetőségekkel magyarázhatók. Az alkalmazkodás, a versenyképesség megőrzése új és új megoldásokat igényel a vállalatok vezetésétől. Ebben a környezetben azok a vállalatok lehetnek sikeresek, amelyek hamar felismerik a változások irányait, s megfelelő válaszokat tudnak adni az új kihívásokra. Nem lebecsülendő ugyanakkor az elméleti fejlődés hatása sem az új stratégiaalkotási módszerek és stratégiatípusok kialakítása terén. Ilyennek tekinthető például az erőforrás- és képességalapú stratégiafelfogás, a hálózatelmélet alkalmazása. Azaz az elméleti és a gyakorlati fejlődés együttesen alakította ki azokat a megközelítéseket, amelyeket a vállalatok a jelenlegi időszakban alkalmaznak.

A fentiekben tárgyalt megközelítéseknek van egy közös jellemvonása, nevezetesen az, hogy azok mind a változáshoz kapcsolódnak. Kissé sarkítva az is mondhatjuk, hogy a szervezetek vezetése a jelen korban a változások vezetését jelenti. Ezzel függ össze az a jelenség is, hogy egyre nagyobb figyelmet kapott a változásvezetés a menedzsment kutatása és oktatása területén. A változásvezetés sikerét biztosíthatják azok a megközelítések, amelyekről a jelen tanulmány szól.

\section{Felhasznált irodalom:}

Ambrosini, V. \& Bowman, C. (2009). What are dynamic capabilities and are they useful construct in strategic management? International Journal of Management Reviews. 11(1). DOI: https://doi.org/10.1111/j.1468-2370.2008.00251.x

Balaton, K. (2015). The Effect of Enterprise Strategies Employed During the Crisis on Growth Options of Companies. Theory, Methodology, Practice, 11 (1), 3-9.

Balaton K. et al. (2010). Stratégiai menedzsment. Budapest: Aula Kiadó.

Balaton K. \& Kerek J. (2012). A stratégiaalkotás folyamatának jellemzői a 2009. évi kérdöives felmérés alapján (Mühelytanulmány). Budapest: Budapesti Corvinus Egyetem, Versenyképesség Kutató Központ.

Balaton K. \& Regele D. (1996). A stratégiaalkotás folyamata a hazai vállalatoknál (Mühelytanulmány). Versenyben a világgal kutatási program. Budapest: Budapesti Közgazdaságtudományi Egyetem, Versenyképesség Kutató Központ.

Barabási, A. L. (2016). A hálózatok tudománya. Budapest: Libri Kiadó.

Bohl, P. (2015). Dynamic capabilities and strategic paradox: a case study. Vezetéstudomány, 46(11) 25-38.

Bowman, G. (2015). The practice of Scenario Planning: An Analysis of Inter- and Intraorganizational Strategizing. British Journal of Management, 27(1) DOI: https://doi.org/10.1111/1467-8551.12098

Burgelman, R. A. (1985). Managing the New Venture Division: Research Findings and Implications for Strategic Management. Strategic Management Journal, 6(1), 39-54. DOI: https://doi.org/10.1002/smj.4250060104

Bühner, R., Dobák, M. \& Tari E. (2002). Vállalatcsoportok. Budapest: Aula Kiadó.

Chikán A. (2008). Vállalatgazdaságtan. Budapest: Aula Kiadó.

Chikán A. (szerk.) (2008). Klaszterek Észak-Olaszországban. Budapest: Rajk László Szakkollégium.

Chikán A. \& Czakó E. (2009). Versenyben a világgal. Vállalataink versenyképessége az új évezred küszöbén. Budapest: Akadémiai Kiadó.

Chikán A. \& Czakó E. (2014). Éllovasból lett sereghajtó Magyarország. Világgazdaság, augusztus 4.

Chikán A. (szerk.) (2014). Gyorsjelentés a 2013. évi kérdöives felmérés eredményeiről. Budapest: Budapesti Corvinus Egyetem, Versenyképességi Kutató Központ.

Cohen, M.D., March, J.G. \& Olsen, J.P. (1972). A garbage can model of organizational choice. Administrative Science Quartely, 17(1) 1-25. DOI: https://doi. org/10.2307/2392088

Dobák M. et al. (2006). Szervezeti formák és vezetés. Budapest: Akadémiai Kiadó.

Dobák M., Tari E., \& Bühner, R. (2002). Vállalatcsoportok - Konszern szervezetek, holding struktúrák. Budapest: Aula Kiadó.

Eisenhardt, K.M. \& Sull, D.N. (2001). Strategy as Simple Rules. Harvard Business Review, January, 107-116.

Evans, P. \& Wurstler, T. (2000). Blown to bits - how the new economics of information transforms strategy. Boston: Harvard Business School Press. 
Fejes, J. (2015). Innovációs kalandozások az elmélettől a stratégiáig. Vezetéstudomány, 46(6). 58-69.

Ford, D., Gaddle, L.-E., Hakansson, H., \& Snehota, I. (2010). Hálózati menedzsment. In Határtalan hálózatok - Az üzleti kapcsolatok menedzsmentjének új szemlélete (pp. 35-55). Budapest: Alinea Kiadó és Rajk László Szakkollégium.

Gelei A. \& Mandják T. (2011). Dzsungel vagy esőerdő? Az üzleti kapcsolatok hálózata. Budapest: Akadémiai Kiadó.

Grant, R. M. (1991). The resource-based theory of competitive advantage: Implicatios for strategy formulation. California Management Review, 33(3) 3-33.

Grant, R. M. (2003). Strategic Planning in a turbulent environment: Evidence from the oil majors. Strategic Management Journal, 24, 491-517. DOI: https://doi. org/10.1002/smj.314

Grove, A. S. (1998). Csúcsteljesitményü vezetés. Budapest: Bagolyvár Kiadó.

Gulati, R., Nohria, N., \& Wohlgezogen, F. (2010). Roaring out of recession. Harvard Business Review, March, 6269.

Hodgkinson, G.P. \& Healey, M.P. (2011). Psychological foundations of dynamic capabilities: reflexion and reflection in strategic management. Strategic Management Journal, 32(13), 1500-1516. DOI: https://doi. org/10.1002/smj.964

Hortoványi L. (2010a). Stratégiai innováció és vállalkozás. In Balaton et al. (Szerk.), Stratégiai Menedzsment. Budapest: Aula Kiadó.

Hortoványi L. (2010b). Vállalkozó vezetés Magyarországon. Vezetéstudomány, 41(4) 21-31.

Imre T. (1996). A szcenáriótervezés mint a stratégiaalkotás része. Vezetéstudomány, 36(6).

Jarzabkowski, P. (2004). Strategy as Practice: Recursiveness, Adaptation, and Practices-in-Use. Organization Studies, 25(4) 529-560. DOI: https:/doi. org/10.1177/0170840604040675

Jarzabkowski, P., Kaplan, S., Seidl, D., \& Whittington, R. (2017). On the Risk of Studying Practices in Isolation: Linking What, Who and How in Strategy Research. Strategic Organization, 14(3), 1-22. DOI: https://doi. org/10.1177/1476127015604125

Kindler J. (1974). A rendszerszemléletü döntéselmélet egyes kérdései figyelemmel a vezetöi döntésekre (Kandidátusi értekezés). Budapest.

Leavitt, H. (1987). Corporate Pathfinders. New York: The Free Press.

McGrath, R. (2013): Transient advantage. Harvard Business Review, March.

March, J.G. (1991). Exploration and Exploitation in Organizational Learning. Organization Science, 2(1), 7187. DOI: https://doi.org/10.1287/orsc.2.1.71
Mintzberg, H. (1987). Crafting strategy. Harvard Business Review. no 4, July

Mintzberg, H. (1990). The Design School: Reconsidering the Basic Premises of Strategic Management. Strategic Management Journal, 11, 171-195. DOI: https://doi. org/10.1002/smj.4250110302

Mintzberg, H. (1994). The rise and fall of strategic planning. Englewood Cliffs, NJ.: Prentice Hall.

Mintzberg, H. \& Quinn, J.B. (1991). The strategy process. Englewood Cliff, NJ.: Prentice Hall.

Mintzberg, H., Ahlstrand, B., \& Lampel, J. (1998). Strategy safari. New York: The Free Press.

Nemes F. (1981). A vezetői szerepfelfogás és magatartás néhány problémája vállalatainknál. Közgazdasági Szemle, 28(7-8), 787-806.

Popadiuk, S. \& Souza Bido D. (2016). Exploration, Exploitation, and Organizational Coordination Mechanisms. Revista de Administracao Contemporanea, 20(2). DOI: https://doi.org/10.1590/19827849rac2016150018

Porter, M. A. (1980). Competitive Strategy. Boston: Harvard Business School Press.

Price, R. W. (2004). Roadmap to entrepreneurial success: powerful strategies for building a high-profit business. New York: Americal Management Association.

Raposo, M., Smallbone, D., Balaton, K., \& Hortoványi, L. (2011). Entrepreneurship, Growth and Economic Development. Cheltenham: Edward Elgar.

Ringland, G. (1998). Scenario planning: Managing for the Future. Chichester: John Wiley and Sons.

Schoemaker, P. J. H. (1995). Scenario Planning: A tool for strategic thinking. Sloan Management Review, January.

Simon, H. A. (1982): A vezetői döntés új tudománya. Budapest: Statisztikai Kiadó.

Smith, W.K. \& Tushman, M. L. (2005). Managing strategic contradictions: A top management model for managing innovation streams. Organization Science, 16(5), 522-536. DOI: https://doi.org/10.1287/ orgs. 1050.0134

Szász L. \& Demeter K. (2017). Ellátásilánc-menedzsment. Budapest: Akadémiai Kiadó.

Thorelli, H. B. (1986). Networks: Between Markets and Hierarchies. Strategic Management Journal, 7(1), 3751. DOI: https://doi.org/10.1002/smj.4250070105

Whittington, R., Basak, J-D., Kwangwon, A., \& Ldovic, C. (2017). Strategic Planners in More Turbulent Times: The Changing Job Characteristics of Strategy Professionals, 1960-2003. DOI: https://doi.org/10.1016/j. lrp.2015.12.021

Wold, C. \& Floyd, S.W. (2013). Strategic Planning Research: Toward a Theory-Driven Agenda. Journal of Management, 43(6), 1-35. DOI: https://doi. org/10.1177/0149206313478185 